\title{
DISSIMULAR PARA SOBREVIVER: ESTRATÉGIAS DE RESISTÊNCIA
}

\author{
Francisca Zuleide Duarte de Souza \\ (Universidade Estadual da Paraíba)
}

\section{RESUMO}

Este artigo analisa a estratégia da dissimulação, delimitada teoricamente por Accetto (2001) e utilizada por Delfina, personagem do romance O Alegre canto da perdiz, da escritora moçambicana Paulina Chiziane. Focaliza, dentre outros aspectos, a relação colonizado versus colonizador, discutindo a condição feminina de subalternidade, que força uma reação aparentemente submissa, a qual supõe a venda do corpo e a rejeição das tradições ancestrais. Interpretam-se as atitudes de Delfina como uma estratégia que mascara o ressentimento contra o domínio abusivo do poder.

PALAVRAS-CHAVE: dissimulação, mulher, subalternidade.

\begin{abstract}
This paper analyzes the strategy of concealment, theoretically bounded by Accetto (2001), and used by Delfina, character in the novel O Alegre Canto da Perdiz of Paulina Chiziane, Mozambican writer. Focuses, among other things, the relationship colonizer versus colonized, discussing the condition of female inferiority that forces a reaction apparently submissive, which assumes the sale of the body and the rejection of their ancestral traditions. To interpret the attitudes of Delfina as a strategy that masks resentment against abusive domain power.
\end{abstract}

KEYWORDS: concealment, woman, subalternity. 


\begin{abstract}
A história patriarcal é que a humanidade se desenvolve contrária à natureza. Enquanto a natureza entrega cada nova geração de úteros maternais, no patriarcado esta identidade natural é substituída pela linhagem paterna, legalmente definida e registrada. Este desenvolvimento impõe a separação entre a humanidade e a natureza, entre filho e mãe, entre eu e inconsciente, entre o sagrado e profano. Desta perspectiva, a maturidade humana é obtida pelo assassinato do dragão e pela aquisição da própria independência.Social e intrapsiquicamente, o tema é a diferenciação.
\end{abstract}

Genia Pauli Haddon

Quando José Dias, personagem de Dom Casmurro, refere-se a Capitu com a conhecida definição "olhos de cigana oblíqua e dissimulada" (ASSIS, 2009, p. 82), adivinhava, no comentário, a estratégia utilizada pela personagem na negociação cotidiana da subalternização e da diferença. Capitu recorria à dissimulação, como o fazem, historicamente, personagens subalternizados. Diante de um conflito em que se ocupa posição desvantajosa, o recurso à dissimulação tem permitido a mulheres, como a outros personagens/pessoas, considerados menos fortes nas relações, um tempo para refletir e articular formas de resistência. Se o comentário era desabonador, e efetivamente era, não perdeu a validade ao indicar um recurso fundamental: dissimular para postergar atitudes apressadas; dissimular como exercício de paciência e cautela, astúcia, diplomacia: dissimulação honesta.

Proposta por Torquato Accetto, essa arte, nas palavras do filósofo italiano, não é outra coisa senão "um véu composto de trevas honestas e decoros forçados, de que não se forma o falso, mas se dá algum repouso à verdade, para demonstrá-la a seu tempo...” (ACCETTO, 2001, p. 19) Habilidade de evitar que as coisas sejam vistas como realmente são, como um ato de suspender a verdade, nem sempre oportuna em certas circunstâncias. Assim, a personagem machadiana deixava entrever um não-dito, ocultado pelos olhos ou frases e atitudes, amaciando o duro julgamento da família que acariciava o sonho de ver Bento Santiago no ministério religioso. Forma de resistir: estratégia de sobrevivência.

Como Capitolina, milhares de seres reais e de papel indiciam o uso dessa arma discreta, mas ninguém precisou dela mais que os subalternizados, vítimas silenciosas do jogo de interesses que a todos arrasta. Afirma Spivak: "A mulher como subalterna não pode falar e quando tenta fazê-lo não encontra os meios de se fazer ouvir" (SPIVAK, 2010, p. 15).

Como sói acontecer em outras sociedades, a luta pela sobrevivência entre as comunidades escravizadas na África colonial passa também por uma espécie de negociação com o colonizador, insaciável na luta da posse absoluta da terra e do homem. Nesse contexto, humanos coisificados eram "usados" para serventias várias, incluídos os serviços sexuais. Digo 
humanos e não particularizo aqui o caso das mulheres, porque, não raro, os homens eram requisitados para préstimos sexuais de patroas e patrões brancos. Logo, a necessidade da dissimulação honesta impõe-se como estratégia de sobrevivência.

A literatura africana de língua portuguesa prodigaliza os exemplos de sujeição sexual de homens e mulheres lutando pela comida e pelo abrigo, usando, muitas vezes, o corpo como moeda. O romance $A$ última Tragédia (1995), de Abdulai Sila, escritor bissau-guineense, traz exemplos da utilização, tanto do homem quanto da mulher, para os assuntos de alcova. Ali, a personagem Ndani ou Maria Daniela (nome cristão imposto pela patroa) aquece o leito do Sr. Leitão, como Zezinho se torna brinquedo sexual da caprichosa patroa.

Usufruir de um pouco mais de açúcar, sal, pão, azeite e outros bens de consumo, usados pelo colonizador, como bacalhau ou cremes de beleza, era sonho que homens e mulheres colonizados nutriam, sem, entretanto, acessarem tais bens com recursos próprios. O usufruto desses bens fundamentais, como alimentação, vestuário e educação, circunscreve-se, para a grande maioria dos ditos indígenas, ou locais, ao âmbito privado da intimidade do patrão branco, não raro proprietário das terras e das pessoas. No caso, o entendimento de intimidade não é outro senão serviços sexuais. Conforme Michelle Perrot: "Corpo desejado, o corpo das mulheres é também, no curso da história, um corpo dominado, subjugado, muitas vezes roubado, em sua própria sexualidade. Corpo comprado também pelo viés da prostituição..." (PERROT, 2007, p. 76)

A travessia dolorosa desses indesejáveis caminhos, incluindo a gestação de filhos mulatos, diz da necessidade diária do jogo da dissimulação, em que a mulher, na expressiva maioria, amoldava-se ao gosto e apetite do colonizador, renegando, muitas vezes, a família e o homem amado, suportes emocionais. Essa é a situação da personagem Delfina, d' O Alegre Canto da Perdiz (2008), da moçambicana Paulina Chiziane.

O romance remonta à colonização e apresenta uma geração de mulheres insatisfeitas com a condição subalternizada em que viviam. Mulheres oriundas de uma vida miserável, ávidas pelo conforto proveniente do leito do homem da branca. Além do desafogo econômico, vislumbravam a possibilidade de branqueamento dos filhos mestiços, os quais adquiriam, dessa forma, um passaporte para uma cidadania que, embora de segunda categoria, renegadora das tradições e fragmentadora da identidade, propiciava escola, mais comida à mesa, adornos e perfumes que, supostamente, as ombreariam às mulheres brancas. A necessidade de sobrevivência empurra, impiedosamente, mulheres colonizadas, em situação de carência material, a um poço sem fundo de humilhações, renúncias e dissimulação. Em determinadas circunstâncias vale quase tudo para ganhar tempo e renegociar. 
É uma travessia dolorosa, que exige sacrifícios até certo ponto incompreensíveis ao senso comum, acarretando para as "vítimas" da necessidade uma dupla discriminação: (1) por sua gente, pela mácula, vergonha e conluio com o dominador, móvel da indigência instaurada pela exploração; (2) pela sociedade dominante, pela intromissão em um núcleo fechado e preconceituoso que não respeitava as diferenças.

Os filhos originários de tais relações dificilmente atingem um estágio de poder econômico e respeitabilidade por trazerem, na sua origem, a marca da desigualdade, o pecado da relação espúria. Da mãe herda-se a mácula que o mulato carregará pela vida afora. Representante de duas raças, o lugar do mulato é o entre-lugar. Seu lugar de pertencimento é o da estranheza, da diferença. Nem branco, nem negro, o sujeito é fruto de ligação não "abençoada". Porém, em relação ao negro, o mulato ocuparia uma posição supostamente melhor. A propósito da tal condição, é elucidativa a passagem abaixo:

Lembra-se de tudo, da terra e do mundo. Onde a cultura dita normas sobre homens e mulheres. Onde o dinheiro vale mais que a vida. Onde o mulato vale mais que o negro e o branco vale mais que todos eles. Onde a cor e o sexo determinam o estatuto de um ser humano. Onde o amor é abstração poética e a vida se tece com malhas de ódio. (CHIZIANE, 2008, p. 27)

A dura reflexão acima é feita por Maria das Dores, filha negra de Delfina e José dos Montes. A personagem foi vendida ao feiticeiro Simba, amante da mãe ambiciosa, que planejava criar um prostíbulo cuja especificidade era a comercialização de moças virgens destinadas ao pagador endinheirado. Das Dores conhecia, de experiência própria, as diferenças entre esses seres na sociedade, uma vez que viveu no lar adúltero de Delfina com o branco Soares e sofreu a discriminação, por parte da própria mãe, por ser negra e não mulata como os filhos da africana com o comerciante branco.

Imolada no leito do feiticeiro sem escrúpulos, das Dores se desequilibrou emocionalmente e conseguiu fugir, aparecendo nua, posteriormente, às margens do rio Licungo, provocando a comunidade local que a critica e a expulsa. Além do desrespeito, a imagem da mulher representava maus presságios. A reação de das Dores era motivada pela mágoa da mãe negra que "amava os brancos, da mãe negra que queria ser branca" (CHIZIANE, 2008, p. 4).

A hierarquia imposta pela sociedade colonial impôs rígidos limites raciais, disseminando preconceitos e interdições, não legitimando relações entre casais multirraciais, extirpando o direito ao lar e à paternidade aos filhos mulatos, também eles, "condenados da terra", como tão bem classificou Fanon (1979), em livro homônimo publicado originalmente em 1961. A regulação, entretanto, não coibiu os abusos sexuais nem sufocou o apetite voraz dos muitos sedutores, amantizados com mulheres ditas "indígenas” que, submetidas ou não, lançavam mão do recurso à dissimulação para sobreviver na zona do iminente perigo. 
Esse recurso à dissimulação não foi adotado pela personagem Suhura, da também moçambicana Lília Momplé, cuja rejeição e resistência ao ataque do Senhor Administrador (que a desejou e a teve à força) causou sua morte. A menina foi como ovelha ao matadouro e literalmente se deixou imolar, não sem antes lutar com todas as forças, tendo como reação um mero "grito rouco e breve... depois o silêncio e a imobilidade total" (MOMPLÉ, 2009, p. 86).

Transida de medo e revoltada, Suhura encontrou a morte na cupidez desenfreada do velho administrador. Não negociou e pagou um alto preço. A avó da menina, porém, não pode prantear a neta, pois dela exigiu-se o silêncio, a dissimulação, já que Ninguém matou Suhura. Casos semelhantes recheiam as narrativas que enfocam relações de poder. Também a literatura brasileira registra histórias de exercício da violência contra mulheres que preferiram a dissimulação à morte certa.

O caso de Maria do Carmo, personagem de A Normalista (publicado em 1893), do escritor cearense Adolfo Caminha, é exemplar. Seduzida pelo padrinho, vai esperar pelo parto em lugar afastado de Fortaleza e quando retorna assume a vida de solteira e de moça casadoura, sem denunciá-lo, pois objetivava casar-se com um Alferes. Do Carmo sempre dissimulou o assédio do suposto protetor a fim de preservar não apenas a madrinha, mas a si mesma. Declarar a paternidade do filho esperado seria uma temeridade, uma vez que de vítima passaria a sedutora. Não raro as esposas se recusam a acreditar na responsabilidade dos maridos, atribuindo à mulher, rival histórica, toda a culpa das relações espúrias. São "os ingênuos e pobres homens", cuja carne, fraca, cede ao assédio de uma mocinha atirada. Em nome da manutenção do casamento, a dissimulação torna-se arma eficaz, que acomoda as coisas.

Voltando ao texto de Chiziane, observa-se ali uma linguagem dura, cruel mesmo, quanto à condição da mulher e às relações afetivas. Seja entre pais e filhos, seja entre amantes, maridos, noivos. Mesmo em relação ao padre, fadado ao celibato, o comentário da narradora é inusitado:

Para aquele povo a procriação é a essência da vida e a vida sexual é tão vital como a gota de água. Ser padre é importante, reconhecem, mas mais importante ainda é gerar um herdeiro para garantir segurança social nos momentos difíceis. Morreram muitos homens na guerra civil e há muitas viúvas por consolar, muitas solteiras esperando amor, é um crime grave um homem dormir sozinho, seja quais forem as motivações da sua crença. Fazia dó ver as jovens espevitadas diante daquela santa presença, a tentar abordar o macho para as coisas da terra, para acabarem frustradas, como abelhas, embatendo nas vidraças frias de uma janela. (CHIZIANE, 2008, p. 36) 
A narradora aproveita para culpar a guerra civil pela falta de homens e não hesita em invocar a natureza do homem para a procriação. Lastima o "desperdício" de macheza do padre, dormindo sozinho, enquanto moças se insinuam e viúvas permanecem com o leito frio. O Alegre Canto da Perdiz é um livro que discute a sexualidade e o direito ao seu livre exercício, mesmo em situações pouco ortodoxas. Moeda de troca, o favor sexual traduzia-se na simulação do prazer, na dissimulação da repulsa e no acesso aos bens materiais.

A narração das aventuras sexuais de Delfina permeia um discurso acusatório e ressentido em que ter nascido negra é o mal maior. Nas palavras cruéis de Delfina, lê-se:

Por culpa da minha mãe que me fez preta e me educou a aceitar a tirania como destino de pobres e a olhar com desprezo a minha própria raça. Por culpa de Simba, meu amante e teu marido que me alimentou com feitiços e fantasias destrutivas. Por culpa da natureza que me deu beleza sobre todas as mulheres. Por culpa do José, pobre e preto, que me alimentava de farinha e peixe seco, enquanto eu, Delfina, queria bacalhau e azeitonas. A culpa é do Soares que me elevou aos céus e me largou no ar. A culpa foi minha, por ter desejado ser o que jamais poderia ser. A culpa é do mundo, que me ensinou a odiar. (CHIZIANE, 2008, p. 44)

Nota-se a violência do discurso da mulher, tomada de profundo ressentimento, sentimento que acompanha os subalternizados, humilhados, abastardados. A rejeição da cor da pele, bem como das consequências que tal sentimento acarreta, transforma Delfina em uma mulher sem escrúpulos, ameaçando os lares dos brancos, recorrendo a feitiçarias, aliciando jovens para a prostituição, traindo, enganando, profanando os sagrados laços da maternidade, sufocando o amor pelo marido "preto e pobre". Para ela, nem sonhar é possível, pois "ser negra é doloroso. Negro não tem deus nem pátria”. (CHIZIANE, 2008, p. 82).

Presa de enorme ressentimento, vingou-se dos brancos, dos negros contra quem tripudiou, da tradição ancestral, das crenças dos brancos, das práticas de feitiçaria. A raiva encravada no peito tornou aquela mulher bonita objeto de satisfação sexual, arma contra o tédio para os brancos, instituição financeira e defesa da pobreza para ela própria. A preocupação exagerada com a manutenção da beleza era a maneira de preservar o patrimônio: a beleza estonteante, a sensualidade à flor da pele. Para conseguir a inexpugnabilidade do seu sentimento, sufocou o amor, o único e verdadeiro sentimento, por José dos Montes e o afeto maternal pelos filhos. Travada para apegos, o projeto de Delfina era apagar a marca da negritude, da humilhação, da pobreza. Por isso entregava-se a quem bem pagasse, dissimulando o prazer que estava longe de sentir. A amargura perpassa suas falas e dá o tom de descrença e cinismo que julgamos adivinhar nas palavras acres que utiliza. 
No bojo do ressentimento, o desejo de liberdade. A busca de ser sem meias medidas, a esperança de um mundo igual. Mas como aceitar uns com tanto e outros sem nada? Como reverter o jogo da miséria, da pobreza, da humilhação? Com que armas lutar? A submissão, a fome e a invisibilidade representam a realidade que impede o acesso a uma vida digna. A vitrine superlotada dos bens que o dinheiro compra, de acesso interdito aos colonizados, acende a ganância de quem já está cansado de peixe seco e farinha azeda. $\mathrm{O}$ apelo do refinamento gastronômico exibido pelo colonizador, os adereços e perfumes de suas mulheres, o luxo das residências e dos meios de transporte, deixam o "indígena" maravilhado. Como se aqueles bens pertencessem a um mundo distante. Porém, para Delfina, aquelas benesses representavam um desafio. Precisava de um aval para o mundo dos brancos, do consumo, do luxo. Documento mais eficiente seria seu leito, carinho, prazer, a disponibilização do corpo, o enxovalhamento da dignidade, da família, das convicções. Misto de anjo e demônio, de escrava e rainha, a mulher tinha a ilusão de conseguir mudar o próprio destino com a profissão ensinada pela mãe, Serafina: "me iniciou nos segredos do travesseiro quando eu ainda sonhava em conquistar o meu diploma de professora numa escola indígena qualquer." (CHIZIANE, 2008, p. 81)

Observa-se a acusação de Delfina mais uma vez contra a mãe: além de fazê-la negra e pobre, empurrou-a à prostituição, sufocando os sonhos da então jovem estudante. Irônico é constatar que, apesar de ter sido vítima, ela não hesitou em repetir o mesmo ato da velha Serafina contra sua filha Maria das Dores, negociando-a com o amante feiticeiro. A lição bem aprendida foi: usar a "mina de ouro", "o celeiro do fundo do corpo" para escapar à miséria. Como se fosse o único caminho possível, situação inarredável. Ao cair de amores por José dos Montes, o aceno de uma nova vida apresentou-se. A sociedade pasmada considerou insana a presumível regeneração da rainha do porto, amante preferida de marinheiros e homens endinheirados, terror das esposas brancas. Delfina casou por uma crença particular: o casamento destrói o amor. A rotina, as privações, o desamparo, dariam cabo do sentimento. Por isso casou. Ao dar sinais de desgaste, o casamento acabou e um branco rico, o Soares, botou casa e assumiu Delfina, dando-lhe os filhos mulatos que desejava.

Como patroa, a mulher revela o ódio pelos seus iguais e o desejo de escravizá-los. O tratamento desigual dispensado aos filhos negros, a arrogância e a rejeição do seu povo levaram o português a abandoná-la para não ser destruído. Decepcionado, Soares deu-se conta da mentira vivida com uma indígena que odiava a própria condição. Com gritos e lágrimas reagiu Delfina, que via esvair-se o seu banco. Ela, que ao separar-se do marido José dos Montes não esboçara qualquer reação, descabelou-se com a perda do branco. Amor? Eis o comentário da personagem sobre o ofício do corpo:

Vocês não sabem o que significa uma vida como a minha. Um corpo sem segredos que se pega, que se paga, 
que se monta e se desmonta. Se o corpo da mulher se gastasse eu já não teria nada lá dentro, de tanto vender à procura de sustento. Que imbecil é esta gente. Deviam olhar para o próprio umbigo mas olham para mim, como se eu tivesse alguma relação com a sua desgraça. A minha vida é fácil? Meu Deus, esta gente não sabe o que diz. Finjo, por orgulho, que sou feliz. É por orgulho que lanço ao mundo este olhar de rainha. Cada homem que me sobe é uma pá de terra que me cobre. Cada moeda que recebo é uma picada na alma, dói. Não se pode ser boa moça num mundo de injustiça. Numa luta desigual vale mais a pena a rendição que a resistência. (CHIZIANE, 2008, p. 81)

A revolta está presente também na forma de responder às críticas. "Gente imbecil", ela rotula as pessoas que a julgam uma pessoa de vida fácil. É a oportunidade para lamentar, de maneira orgulhosa e arrogante, a humilhação, o abastardamento da vida. Dissimulando sempre, vende a ilusão de felicidade, de realização. Forma de resistência aparentemente pacífica e bastante eficiente. A rebelião em mundo injusto, segundo ela, não resulta: é melhor ceder. Diríamos: recuar. Uma boa recuada é sinal de valentia. A submissão, nesse caso, não é acomodada, nem pacífica. Há sempre um vulcão prestes a explodir e um ressentimento que não se apaga com os calores do sexo. A saciedade buscada não é física. É mágoa que milhões não compensam. Renúncia da vida afetiva, desprezo do sentimento, endurecimento de alma, não mitigado com dádivas materiais. Falta que avassala todo e qualquer resquício de ternura pelos parceiros do jogo. Rios de amargura e muita dor, sem alegria, mesmo breve. O enterro da dignidade a cada parceiro. A identidade em frangalhos no turbilhão de ódios e culpa. Atribuída à mãe, ao pai, aos maridos, amantes, à raça, à pobreza. Miséria forjadora de infelizes. Mulheres prostituídas, virgens estupradas, crianças abusadas, maridos traídos. Vilipendiados. Contar a debitar à miséria extrema, ao descaso de um processo de invasão e tentativa de anulação dos legítimos donos da terra.

Declarando-se contadora de histórias, Chiziane mescla a narrativa de contos tradicionais e mitos, reportando-se sempre às fábulas sobre um mundo dominado pelas mulheres. Entre fato e fábula, $O$ Alegre canto da Perdiz evidencia uma situação de subalternidade e tirania bem definida por Choderlos de Laclos na citação abaixo:

A natureza só cria seres livres; a sociedade só faz tiranos e escravos [...] na união dos dois sexos, as mulheres, normalmente mais fracas, tiveram de ser, em geral, oprimidas; aqui os fatos vem corroborar as teorias. Olhem para o universo conhecido e verão por todo o lado o homem forte e tirano, a mulher, fraca e escrava; verão que se por vezes ela tem a habilidade de atar as mãos do seu senhor e tomar o comando, este caso é extremamente raro. Quando percorremos 
a história dos diferentes povos e examinamos as leis promulgadas e os costumes estabelecidos relativamente às mulheres, somos tentados a acreditar que elas apenas cederam e não aderiram, ao contrato social, que primitivamente foram subjugadas e que o homem tem sobre elas um direito de conquista de que fez uso com todo o rigor. (LACLOS, 2002, p. 99-100, grifos nossos)

Ao escrever sobre a educação feminina, Laclos é pontual ao destacar o contrato de submissão a que as mulheres foram historicamente submetidas, atribuindo essa condição à sua presumível fragilidade. Entretanto, esclarece que a mulher, ao ceder, não está concordando. Hábeis na dissimulação, algumas raras mulheres, segundo o autor, dominam o homem, revertem o milenar jogo entre patrão e escrava, ratificando a ideia de que a companheira invisível e silenciosa respondia mais que se imagina pelo sucesso ou fracasso do marido. Confinadas nas salas de prendas domésticas, lugar de negociação, jovens e velhas sonhavam, planejavam, rebelavam-se. Sob leis antiquadas e restritivas, não tinham direito à instrução, o que contribuía para o isolamento de algumas e despreparo de outras, em função do exílio doméstico. O silêncio feminino refletia submissão e tática, mas nunca incapacidade de lutar pelo seu direito. Dessa mulher ordeira e silenciosa esperava-se, segundo Monika von Koss, "habilidade para lidar com os relacionamentos e os sentimentos, adaptando e moldando-se aos desejos das pessoas que a cercam" (KOSS, 2000, p. 215).

Definidos os papéis, coube também às mulheres o trabalho pesado no campo, além de procriar braços fortes para os negócios e manter a ordem. Responsável pelo cuidado de casa, campo e filhos, sujeitava-se, e sujeita-se ainda, expressivo número de mulheres aos apetites de maridos nem sempre gentis e afetuosos.

O poder de sedução exercido pelas mulheres recrudesceu, no período colonial, somando-se à ausência inicial de mulheres ocidentais. A colonização inglesa, segundo Stearns (2007), desaconselhava a ida das esposas para as colônias, o que obrigava os homens ao consórcio com mulheres locais. Por outro lado, o temor da sedução ou do embruxamento por parte das africanas afastava as mulheres do serviço doméstico, criando um novo tipo de trabalho para os homens. Esses criados, como já foi dito e ora se enfatiza, podiam ser requisitados para serviços sexuais de patrões e patroas.

O texto de Chiziane salienta o comércio do sexo, mas abstém-se de tratar as relações homoeróticas. Pranto derramado pela degradação, pelo vilipêndio, O Alegre canto da perdiz descreve o périplo de mulheres que usaram raivosa e desesperadamente seus encantos físicos sem, entretanto, se entregarem de fato. Percebe-se o rancor contra o macho nas mais duras descrições: 
A alegria e a liberdade são filhas do matriarcado, onde se obedece às leis da natureza porque só a mulher conhece o verdadeiro pai dos filhos que tem. Os homens são simples reprodutores, seres menores. Por isso eles devem pagar por tudo. Pelo lazer, pelo prazer que é concedido pelas mulheres. Pagar pela maternidade e pela dignidade que as mulheres lhes dão, pois sem elas não construiriam família.

No mundo onde o homem manda os filhos são de um só. A família tem peso de chumbo, tecido por laços do mesmo sangue. Mas é um reino de lágrimas e de sofrimento. Com violência, os homens mantém as mulheres fiéis a paulada. A violência é produto do patriarcado, porque os homens roubaram o poder às mulheres. (CHIZIANE, 2008, p. 271-272)

A imputação do sofrimento e da violência ao homem promove uma espécie de desleitura da formação familiar cristã tradicional. A presença da mulher torna-se imperativa para a formação e manutenção da família, daí ser não apenas necessária, mas imprescindível. Dominar o homem com sutilezas e dissimulações é lição aprendida cedo por cada menina. Guardar para si própria o segredo da real paternidade dos filhos era trunfo e arma poderosa, hoje ameaçada pela ciência e seus testes de DNA. Evidentemente, nas sociedades primitivas e com difícil acesso à evolução científica, a incerteza da paternidade ainda paira sobre o homem. Essa seta é dirigida certeiramente ao orgulhoso macho que se julga dono de tudo e de todos.

O discurso da personagem arrogante e autossuficiente resvala para a ofensa dirigida à parte fragilizada do comportamento masculino: a virilidade de macho, a competência procriativa e o poder de dominar. "Bicho indestrutível e ambicioso... escravizou a mulher e instituiu o patriarcado, mantendo, com violência e palavras, as mulheres fieis num reino de lágrimas e sofrimentos" (CHIZIANE, 2008, p. 271).

Esse mundo triste e sem liberdade, nem sempre foi assim no que tange à cultura africana. Em alguns países onde vigorava o matriarcado, as mulheres exerciam funções no comércio, oficiavam no culto, lideravam o clã. A colonização ocidental, ao aportar no continente africano, segundo Stearns, não aprovou o costume de alguns locais e tratou de estabelecer o patriarcado com mão de ferro:

As questões de gênero variavam nas diferentes partes do enorme subcontinente ao sul do Saara, em geral as mulheres tinham mantido várias formas de poder antes do contato colonial. Com frequência, trabalhavam em diversas tarefas na agricultura e assumiam responsabilidades significativas no comercio de mercadorias. [...] os papéis tradicionais de trabalho, para as mulheres, pareciam pesados, além de as impedir de 
dedicar a atenção adequadas às suas famílias. Assim, uma lei de 1929, na região que hoje é Gana, levou à prisão mulheres comerciantes, junto com prostitutas. (STEARNS, 2007, p. 154)

Esta intervenção representou um sem número de perdas compensadas, posteriormente, em parte, com acesso à instrução e um relativo espaço para elas se fazerem ouvir. Novas atividades também surgiram, mas a grande maioria permaneceu na machamba, ocupação tradicional, e no amanho da casa. $\mathrm{O}$ apelo consumista falando alto gerou mulheres que, por falta de outra opção e revoltadas contra sua condição de carência, buscavam na prostituição um meio de subsistência. $O$ recurso à dissimulação permeia esse discurso feminino magoado, ressentido, marcado pela baixa autoestima, em uma sociedade para a qual a mulher,

é peça que se compra e se vende. Selo de contrato. Moeda de troca. Hipoteca. Multa. Sobrevivência... Sociedade onde viver bem é uma questão financeira ou o mais importante para uma mulher não é um diploma, mas a sorte na vida e a táctica de caçar um homem que sirva. (CHIZIANE, 2008, p. 56)

O texto acima é parte das lições ministradas por Delfina à filha mulata que estava para se casar. Naquela ocasião esperava-se um discurso de fé na vida, porque afinal realizava-se o sonho de assistir à ascensão social da filha, formada, noiva de homem bem posto na vida, rico, amoroso. Mas a frustrada mulher, no seu ressentimento, desvaloriza o diploma, projeto malogrado da própria juventude, e deixa escapar a máxima aprendida com a mãe, Serafina. Virgindade é moeda de troca, único investimento viável. A sedução, estratégia para garantir conforto, segurança e...

\section{REFERÊNCIAS BIBLIOGRÁFICAS}

ACCETTO, Torquato. Da Dissimulação Honesta. Trad. Edmir Missio. São Paulo: Martins Fontes, 2001.

ASSIS, Machado de. Dom Casmurro. Lisboa: D. Quixote, 2009.

CAMINHA, Adolfo. A Normalista. Rio de Janeiro: Ediouro, 1969.

CHIZIANE, Paulina. O alegre canto da perdiz. Lisboa: Caminho, 2008.

FANON, Franz. Os Condenados da Terra. Rio de Janeiro: Civilização Brasileira, 1979.

KOSS, Monika von. Feminino + Masculino: uma nova coreografia para a eterna dança das polaridades. São Paulo: Escrituras Editora, 2000.

LACLOS, Choderlos. Da educação das mulheres. Trad. Luis Leitão. Lisboa: Antígona, 2002.

MOMPLÉ, Lilia. Ninguém matou Suhura. Maputo: SARL, 2009. 
PERROT, Michelle. Minha história das mulheres. Trad. Ângela M. S. Correa. São Paulo: Contexto, 2007.

SPIVAK, Gayatri Chakravorty. Pode o subalterno falar?. Trad. Sandra Regina Goulart Almeida, Marcos Pereira Feitosa, André Pereira Feitosa. Belo Horizonte: Editora UFMG, 2010.

STEARNS, Peter N.. História das relações de gênero. Trad. Mirna Pinsky. São Paulo: Contexto, 2007.

Recebido para publicação em 04/11/2012

Aprovado em 17/02/2013 